\title{
Sleep Disorders in Stroke: An Update on Management
}

\author{
Hongxia Cai ${ }^{1}$, Xiao-Ping Wang ${ }^{*}$, Guo-Yuan Yang ${ }^{2 *}$ \\ ${ }^{1}$ Department of Neurology, Tong-Ren Hospital, Shanghai Jiao Tong University School of Medicine, Shanghai, \\ China. ${ }^{2}$ Med-X Research Institute and School of Biomedical Engineering, Shanghai Jiao Tong University, \\ Shanghai, China.
}

[Received May 30, 2020; Revised July 7, 2020; Accepted July 7, 2020]

\begin{abstract}
Stroke is a leading cause of disability and mortality all over the world. Due to an aging population, the incidence of stroke is rising significantly, which has led to devastating consequences for patients. In addition to traditional risk factors such as age, hypertension, hyperlipidemia, diabetes and atrial fibrillation, sleep disorders, as independent modifiable risk factors for stroke, have been highlighted increasingly. In this review, we provide an overview of common types of current sleep disturbances in cerebrovascular diseases, including insomnia, hypersomnia, breathing-related sleep disorders, and parasomnias. Moreover, evidence-based clinical therapeutic strategies and pitfalls of specific sleep disorders after stroke are discussed. We also review the neurobiological mechanisms of these treatments as well as their effects on stroke. Since depression after stroke is so prevalent and closely related to sleep disorders, treatments of post-stroke depression are also briefly mentioned in this review article.
\end{abstract}

Key words: stroke, sleep disorders, treatment strategy, post-stroke depression

Sleeping is one of the most important physiological processes of our body [1, 2]. Approximately $20-40 \%$ of one day is sleep time, and during this period sleep exerts multiple functions in our body. For example, it relieves mental fatigue, improves memory, regulates metabolism, and plays key roles in tissue regeneration, synaptic stability, and immune regulation [3, 4]. Numerous detrimental influences of sleep disorders have been described: decreased physical capacities (fatigue, dizziness, injuries, and mortality), psychiatric symptoms (anxiety, depression, and mania) and impaired cognitive abilities (low memory recall and learning abilities and dementia) [4]. Despite the damage mentioned above, we are forced to curtail sleep time due to social and workrelated activities. If the synchronization between the outside surroundings and circadian rhythms is lost or if the rhythm itself fails to work, sleep disorders will happen
[5]. Sleep disorders are mainly classified as insomnia, hypersomnia, sleep-related breathing disorders, circadian rhythm sleep-wake disorders, sleep-related movement disorders, parasomnias, and other sleep disorders. Each diagnosis possesses specific coding information [6, 7]. During recent years, evidence of sleep disorders in neurological diseases is growing rapidly $[8,9]$. Several diseases such as Parkinson's disease, multiple system atrophy and dementia with Lewy bodies (DLB) display various sleep disturbances including rapid eye movement (REM) sleep behavior disorder (RBD), insomnia and restless leg syndrome (RLS) [10]. Apart from these neurodegenerative diseases, one common neurological disease - stroke, has also been found to be closely associated with sleep disorders.

*Correspondence should be addressed to: Dr. Xiao-Ping Wang, Tong-Ren Hospital, Shanghai Jiao Tong University School of Medicine. Shanghai, China. Email: x_p_wang@sjtu.edu.cn; Dr. Guo-Yuan Yang, Shanghai Jiao Tong University, Shanghai, China. Email: gyyang@sjtu.edu.cn.

Copyright: ( $\odot 2020$ Cai H et al. This is an open-access article distributed under the terms of the Creative Commons Attribution License, which permits unrestricted use, distribution, and reproduction in any medium, provided the original author and source are credited. 
Stroke is a detrimental disease that affects 15 million patients worldwide each year, accounting for one-third of patient deaths and two-thirds of severe disabilities [11]. Despite the declining stroke incidence and death rates over the past 20 years, the number of survivors after stroke is still not increasing $[12,13]$. Typical stroke symptoms are characterized by paralysis, diplopia, ataxia, numbness, and vertigo. For severe stroke, patients present with bilateral blindness, quadriplegia, unconsciousness, or even death $[14,15]$. Although stroke as a heterogeneous disease with over 150 known causes, it is generally classified by cerebral ischemia and hemorrhage, subarachnoid hemorrhage, cerebral venous thrombosis, and spinal cord stroke [16, 17]. Among them, ischemic stroke accounts for about $80 \%[11,18]$. Classical stroke risk factors mainly include carotid stenosis, hypercholesterolemia, high blood pressure, and atrial fibrillation. In addition to these factors, other possible risk factors include migraine, chronic kidney disease, and diabetes mellitus [14, 19]. Various unhealthy lifestyles such as a high-fat diet, physical inactivity, cigarette smoking, environmental pollution, alcohol or drug abuse, and emotional stress also contribute to stroke events [12, 20]. Since sleep disorders play key roles as both a risk factor and a factor in stroke recovery and prognosis [21], in this review, we will mainly discuss several strokerelated sleep disorders as well as their treatment strategies.

\section{Insomnia and stroke}

Insomnia, as a prevalent clinical problem, indicates sleep reduction and difficulty in starting or maintaining sleep. Before the diagnosis, the patients should provide a complete sleep history, recent physical and emotional state, and medication usage. More than 30 minutes and over 3 times per week of awakening complaints should be considered insomnia. Symptoms lasting less and more than 3 months are defined as short-term and chronic insomnia, respectively [10].

As high as approximately $50 \%$ of patients may present with insomnia during the first few months after stroke. One-third of patients present with insomnia for the first time, and the remaining patients already suffered from it previously [22, 23]. Insomnia after stroke is usually due to environmental factors or comorbidities such as depression, which will be mentioned in the latter part of the review. Particularly, insomnia may be directly associated with brain injury [21]. It was reported that ponto-mesencephalic stroke resulted in a near-complete loss of sleep, and thalamic stroke led to a lack of brain waves [22]. It was also reported that supratentorial, left hemispheric or paramedian thalamic stroke decreased non-REM (NREM), while right hemispheric stroke decreased REM [24]. In addition, insomnia was also related to damage to some specific areas of the cerebral cortex in patients with penetrating brain damage [25]. Moreover, several drugs used to treat stroke, or its comorbidities may affect sleep. For example, stroke patients with hypertension take medications such as betablockers, clonidine or diuretics, which can disrupt REM sleep, induce insomnia, and lead to early morning awakening, nightmares or painful calf cramps during sleep. For stroke patients with psychiatric symptoms, they would take selective serotonin reuptake inhibitors (SSRIs) such as sertraline or paroxetine, which decrease REM sleep and increase daytime fatigue [10]. Furthermore, insomnia might be the potential risk factor for stroke. A study found that short sleep (less than 5 to 6 hours per night) could reliably predict stroke after adjusting for confounding factors [26]. One cohort study including 21,438 insomniacs and 64,314 noninsomniacs suggested that insomniacs group had a $54 \%$ higher stroke risk than noninsomniacs, which was evident among young adults. The mechanisms by which insomnia may lead to stroke development are still unknown, although neuroinflammation may play a role. Furthermore, chronic stress from sleep loss may be another possible mechanism of elevated stroke risk [21, 27]. For patients with acute stroke, insomnia was not only associated with poor life satisfaction but also with severe stroke since sleep absence can aggravate brain damage and impede neurogenesis [28, 29].

\section{Treatments of insomnia in stroke}

For the treatment of insomnia, stroke patients should prevent themselves from experiencing noise and light (remaining in quiet rooms at night). One recommended treatment is cognitive-behavioral therapy (CBT). CBT can be applied in patients who need long-term management of chronic insomnia. It seems to reduce insomnia effectively after stroke. However, the long-term physical and mental benefits do not seem to be apparent and need to be addressed with larger samples in the future $[30,31]$.

For pharmacological therapy, benzodiazepines are not recommended since they may aggravate

breathing-related sleep disorders as well as induce the reappearance of motor deficits. It was reported that antidepressants such as mianserin may improve insomnia after stroke [32,33]. Zolpidem, which has relatively fewer effects on cognition and muscle tension, might improve stroke prognosis by increasing brain-derived neurotrophic factor (BDNF) secretion and protecting the neurovascular unit in acute stroke [21, 34, 35]. Nevertheless, we should be aware that hypnotics also increased stroke risk in some researches. Evidence shows that zolpidem is related to ischemic stroke risk with increasing doses, and annual use 
of over 4 grams or 95 days use of benzodiazepines increased stroke incidence [36]. Furthermore, the use of hypnotics has been related to medication dependence and elevated the risk of falls when the elderly walked to the toilet at night. Other problems such as impulse control disorders including gambling, shopping, or eating might also come up [10]. Therefore, a risk-safety balance needs to be further assessed before utilizing hypnotics to treat post-stroke insomnia.

Several randomized controlled trials have suggested that acupuncture (Shen-Men and Nei-Kuan acupoints) is a helpful tool for patients with insomnia after stroke (Table 1) [37, 38]. One study indicated that with the
Pittsburgh sleep quality index (PSQI) evaluation, stroke patients with insomnia receiving acupuncture (Shen-Men and Si-Shen-Chong acupoints) tended to exhibit more effective outcomes than those taking drugs [39]. However, other trials have suggested that acupuncture stimulation (Da-Zhui and Sheng-Shu acupoints) shows similar therapeutic efficacy to specific hypnotics [40, 41]. All these findings suggest that acupuncture is a promising method for treating insomnia after stroke. Based on these outcomes, further large multicentre studies to confirm the efficacy of acupuncture in treating post-stroke insomnia are needed.

Table 1. Randomized clinical trials on treatments of insomnia or hypersomnia after stroke.

\begin{tabular}{|c|c|c|c|c|c|}
\hline Study & Trial Type & Patients & $\begin{array}{l}\text { Number } \\
\text { Enrolled }\end{array}$ & Treatments & Primary Outcome \\
\hline $\begin{array}{l}\text { Nguyen et } \\
\text { al [31] }\end{array}$ & $\begin{array}{l}\text { Single-centre, } \\
\text { parallel two- } \\
\text { group pilot } \\
\text { randomized trial }\end{array}$ & $\begin{array}{l}\text { Stroke, } \\
\text { insomnia }\end{array}$ & $\begin{array}{l}15 \\
\text { (intervention:9; } \\
\text { control: 5) }\end{array}$ & $\begin{array}{l}8 \text { weekly sessions of } \\
\text { CBT and } 6 \text { continued } \\
\text { rehabilitation. }\end{array}$ & $\begin{array}{l}\text { Insomnia was improved instantly } \\
\text { after therapy (ISI } 3.89,95 \% \text { CI: } \\
0.65 \text { to } 7.14 \text { ) but was no longer } \\
\text { superior to control after follow-up } \\
\text { (ISI } 5.25,95 \% \text { CI: }-0.80 \text { to } 11.30 \text { ) }\end{array}$ \\
\hline $\begin{array}{l}\text { Palomaki et } \\
\text { al [32] }\end{array}$ & $\begin{array}{l}\text { Randomized, } \\
\text { double-blind, } \\
\text { controlled trial }\end{array}$ & $\begin{array}{l}\text { Acute } \\
\text { ischemic } \\
\text { stroke, } \\
\text { insomnia }\end{array}$ & $\begin{array}{l}100 \text { (intervention: } \\
\text { 51; control: } 49 \text { ) }\end{array}$ & $\begin{array}{l}\text { Mianserin } 60 \mathrm{mg} / \mathrm{d} \text { or } \\
\text { placebo for } 1 \text { year, } \\
\text { follow up for } 6 \\
\text { months. }\end{array}$ & $\begin{array}{l}\text { Mianserin treatment showed } \\
\text { beneficial effects on insomnia } \\
\text { recovery in stroke patients (OR: } \\
4.04,95 \% \text { CI: } 1.33 \text { to } 12.2 \text { ). }\end{array}$ \\
\hline $\begin{array}{l}\text { Kim et al } \\
{[37]}\end{array}$ & $\begin{array}{l}\text { Randomized } \\
\text { controlled trial }\end{array}$ & $\begin{array}{l}\text { Hospitalized } \\
\text { stroke, } \\
\text { insomnia }\end{array}$ & $\begin{array}{l}\text { Final } 30 \\
\text { (intervention: } 15, \\
\text { control: } 15 \text { ) }\end{array}$ & $\begin{array}{l}\text { Acupuncture } \\
\text { intradermally for } 2 \\
\text { days. }\end{array}$ & $\begin{array}{l}\text { Real acupuncture improved } \\
\text { insomnia more than sham } \\
\text { acupuncture }(\mathrm{P}<0.05) \text {. }\end{array}$ \\
\hline $\begin{array}{l}\text { Lee et al } \\
{[38]}\end{array}$ & $\begin{array}{l}\text { Randomized, } \\
\text { double-blind, } \\
\text { crossover trial }\end{array}$ & $\begin{array}{l}\text { Hospitalized } \\
\text { stroke, } \\
\text { insomnia }\end{array}$ & $\begin{array}{l}\text { Final } 52 \\
\text { (intervention: } 27 \text {; } \\
\text { control: } 25 \text { ) }\end{array}$ & $\begin{array}{l}\text { Acupuncture of } \\
\text { Shen-Men and Nei- } \\
\text { Kuan for } 3 \text { days. }\end{array}$ & $\begin{array}{l}\text { Acupuncture was useful and } \\
\text { decreased sympathetic } \\
\text { hyperactivities for post-stroke } \\
\text { insomnia }(\mathrm{P}<0.05) \text {. }\end{array}$ \\
\hline $\begin{array}{l}\text { Tang et al } \\
\text { [40] }\end{array}$ & $\begin{array}{l}\text { Randomized } \\
\text { controlled trial }\end{array}$ & $\begin{array}{l}\text { Stroke, } \\
\text { insomnia }\end{array}$ & $\begin{array}{l}\text { Final } 119 \\
\text { (intervention: } 40 \text {; } \\
\text { medication } \\
\text { control: } 40 \text {; } \\
\text { placebo control: } \\
\text { 39) }\end{array}$ & $\begin{array}{l}\text { Low-frequency } \\
\text { electric stimulation } \\
\text { on Da-Zhui and } \\
\text { Sheng-Shu acupoints } \\
\text { once per day for } 30 \\
\text { days. }\end{array}$ & $\begin{array}{l}\text { Acupoint stimulation and } \\
\text { estazolam had a similar effect, and } \\
\text { both were better than the placebo } \\
\text { group }(95.0 \% \text { versus } 92.5 \% \text { versus } \\
17.9 \%) .\end{array}$ \\
\hline $\begin{array}{l}\text { Hou et al } \\
{[41]}\end{array}$ & $\begin{array}{l}\text { Randomized } \\
\text { controlled trial }\end{array}$ & $\begin{array}{l}\text { Stroke, } \\
\text { insomnia }\end{array}$ & $\begin{array}{l}90 \text { (intervention: } \\
\text { 30; medication } \\
\text { control: } 30 \text {; } \\
\text { placebo control: } \\
30 \text { ) }\end{array}$ & $\begin{array}{l}\text { RTAS for } 40 \mathrm{~min} \\
\text { once a day; } 2.5 \mathrm{mg} \\
\text { diazepam per day; } \\
\text { placebo capsule per } \\
\text { day for } 1 \text { month. }\end{array}$ & $\begin{array}{l}\text { RTAS was as effective as diazepam } \\
\text { in treating insomnia after stroke, } \\
\text { and both were better than the } \\
\text { placebo group }(86.7 \% \text { versus } \\
90.0 \% \text { versus } 20.0 \%) \text {. }\end{array}$ \\
\hline $\begin{array}{l}\text { Li Pi Shan } \\
\text { et al [133] }\end{array}$ & $\begin{array}{l}\text { Randomized, } \\
\text { double-blind, } \\
\text { crossover trial }\end{array}$ & $\begin{array}{l}\text { Stroke or } \\
\text { brain- } \\
\text { injured, } \\
\text { insomnia }\end{array}$ & $\begin{array}{l}\text { Final } 18(9 \\
\text { received } \\
\text { treatment A, } 9 \\
\text { received } \\
\text { treatment B) }\end{array}$ & $\begin{array}{l}\text { Treatment A: } 0.5-1.0 \\
\text { mg lorazepam for } 7 \\
\text { days }+3.75-7.5 \mathrm{mg} \\
\text { zopiclone for } 7 \text { days; } \\
\text { Treatment B: reverse } \\
\text { order of A. }\end{array}$ & $\begin{array}{l}\text { Zopiclone showed the same effect } \\
\text { as lorazepam on insomnia in stroke } \\
\text { or brain-injured patients }(\mathrm{P}>0.05) \text {. }\end{array}$ \\
\hline $\begin{array}{l}\text { West et al } \\
\text { [49] }\end{array}$ & $\begin{array}{l}\text { Quasi- } \\
\text { randomized, } \\
\text { controlled trial }\end{array}$ & $\begin{array}{l}\text { Stroke, } \\
\text { sleepiness } \\
\text { and fatigue }\end{array}$ & $\begin{array}{l}\text { Final } 71 \\
\text { (intervention: } 39 \text {; } \\
\text { control: } 32 \text { ) }\end{array}$ & $\begin{array}{l}\text { Rehabilitation in a } \\
\text { unit with naturalistic } \\
\text { light; the control with } \\
\text { standard lighting for } \\
\text { more than } 2 \text { weeks. }\end{array}$ & $\begin{array}{l}\text { No improvement of hypersomnia } \\
\text { in the intervention group (PSQI: - } \\
13.0 \%, 95 \% \text { CI: }-37.1 \% \text { to } 20.5 \% \text { ). }\end{array}$ \\
\hline
\end{tabular}

Abbreviations: CBT: cognitive behavior therapy; CI: confidence interval; ISI: Insomnia Severity Index; OR: odds ratio; PSQI: Pittsburgh sleep quality index; RTAS: repetitive transcranial acupuncture stimulation. 


\section{Hypersomnia and stroke}

For patients, frequent symptoms of hypersomnia are excessive daytime sleepiness (EDS) and fatigue. Fatigue can persist for years, while EDS improves during the first month after stroke [21, 42]. Hypersomnia mostly appears after subcortical and ponto-mesencephalic stroke. Stroke in the paramedian thalamus is one of the most classic forms of post-stroke EDS. These lesion sites affect the pontine tegmental reticular formation and the paramedian nuclei of the thalamus, facilitating hypersomnia formation [43]. Furthermore, large cerebral lesions and lesions involving the left hemisphere and the anterior regions also result in increased hypersomnia [24]. Patients exhibit severe hypersomnia behavior accompanied by lack of attention, memory and cognition, possibly due to damage to specific physiological functions of the sleep-wake cycle $[44,45]$. In general, EDS improves within months, while other defects such as cognitive problems persist. For some patients with bilateral stroke, hypersomnia may even last for years [21, 42].

Hypersomnia also affects stroke. Studies have shown that sleeping over nine hours per night strongly predicts stroke events after eliminating confounding factors [26]. It has also been reported that excessive sleep is associated with a higher risk of stroke than short sleep [46]. A crosssectional analysis (1,244 stroke-free participants recruited for MRI) found that subcortical white matter hyperintensities were correlated with long sleep, suggesting that hypersomnolence might be attributed to small vessel disease of the brain [47]. Furthermore, hypersomnia impeded stroke recovery, and patients had more disability and more chances of referral to convalescent hospitals [48]. The potential mechanisms were elusive, but abnormal lipid metabolism, inflammation and atherosclerosis might be involved [46].

\section{Treatments of hypersomnia in stroke}

Therapy for post-stroke hypersomnia is full of challenges. One study reported that sleep structures in thalamic stroke survivors were ameliorated by taking medications such as modafinil or methylphenidate [44]. It was also reported that satisfactory effects on neurological recovery were observed after methylphenidate or levodopa treatment. These might be partly related to ameliorated wakefulness [22]. Antidepressants may also improve hypersomnia. West et al suggested no evident improvement in natural light interference compared with standard lighting in the rehabilitation unit (Table 1) [49]. High-quality randomized clinical trials are still lacking. Whether hypersomnia treatment improves stroke prognosis and recurrence risk is unclear and needs to be revealed.

\section{Breathing-related sleep disorders (BSDs) and stroke}

According to the diagnostic and statistical manual of mental disorders of the $5^{\text {th }}$ edition (DSM-5), BSDs include obstructive sleep apnea (OSA), central sleep apnea (CSA), sleep-related hypoventilation, and circadian rhythm sleep-wake disorders [50]. The most frequent screening questionnaires on BSDs are the Berlin questionnaire (BQ), Epworth sleepiness scale (ESS), and STOP-BANG questionnaire (SBQ). The polysomnography (PSG) assay is regarded as the optimal diagnostic standard for OSA and accurately monitors capillary oxygen saturation, nasal airflow and respiratory movements [51]. BSDs are severe in acute cerebrovascular diseases. An investigation on the population with acute stroke and transient ischemic attack (TIA) revealed that BSDs were related to patients with wake-up stroke and structural defects of the heart. The probable explanation might be a paradoxical embolism resulting from BSDs [21]. In a systematic review of stroke and TIA patients, 10 studies all reported that BSD increased vascular events or mortality [52]. BSDs might improve with stroke recovery but elevated mortality continuously after the acute stage [53, 54].

Among BSDs, OSA is the most prevalent form. Obstructive upper airway induces paroxysmal hypoxia and leads to OSA during the process of sleeping. The palate and tongue are the primary blocked locations [22, 53]. In addition, an abnormal airway pressure change appears after airway obstruction. Hypoxia is accompanied by altered intrathoracic pressure, blood pressure fluctuations, and sympathetic activation, with possible mechanisms of endothelial dysfunction, oxidative stress, atherosclerosis, cardiac arrhythmia, hypercoagulation, paradoxical embolisms, and heart failure. All these events could induce stroke; therefore, OSA is a known risk factor for cerebrovascular diseases [55]. Studies have shown that approximately $4-7 \%$ of the adult OSA population suffers from cerebral ischemia and cardiovascular death, and approximately $60 \%$ of stroke patients suffer from OSA $[22,56,57]$. OSA also has negative impacts on the recovery and recurrence of stroke, whether from short or long-term observations [58]. One study reported that sleep apnea was closely associated with mood depression, delirium, and impairment in reaction and activities of daily living (ADL) abilities [59, 60]. In OSA, abnormal pathways such as paroxysmal hypoxia and autonomic activation are triggered and ultimately affect atrial fibrillation and cerebral vaso-regulation [61]. Nocturia, one common problem for senior stroke patients, is becoming a warning of severe OSA and reflects the tendency of cerebrovascular diseases [62]. In OSA patients, the lesion sites of stroke (both ischemic and hemorrhagic) were distributed in the cerebral 
hemispheres, brainstem and cerebellar areas [63]. Therefore, it seemed unrelated to specific infarct lesion sites in patients with OSA.

CSA possesses lower morbidity than OSA, but it is prevalent in specific populations with cardiac and cerebrovascular diseases. CSA is characterized by a syndrome of periodic airflow decline or interruption dysregulated by central ventilation. Weak respiration lowers blood oxygen levels and may finally induce stroke or heart failure. Thus, CSA is an independent stroke risk factor and improves with stroke recovery. Furthermore, CSA is negatively correlated with stroke prognosis [64].
The brainstem is the most frequently described stroke position in patients with CSA [65]. It was found that frontal lobe stroke is related to respiratory apraxia, pontine stroke to central hypoventilation, inferomedial posterior pons stroke to apneustic respirations, and medullary stroke to Ondine's curse [24]. Cheyne-Stokes breathing has been reported to be the primary type of CSA but seems unrelated to specific lesion sites [59, 66]. In rare cases, stroke patients might suffer from complex sleep apnea (both OSA and CSA), which is likely to be neglected [66, 67].

Table 2. Randomized clinical trials on treatments of OSA after stroke.

\begin{tabular}{|c|c|c|c|c|c|}
\hline Study & Trial Type & Patients & $\begin{array}{l}\text { Number } \\
\text { Enrolled }\end{array}$ & Treatments & Primary Outcomes \\
\hline $\begin{array}{l}\text { Bravata et } \\
\text { al [73] }\end{array}$ & $\begin{array}{l}\text { Randomized } \\
\text { home-based } \\
\text { study }\end{array}$ & $\begin{array}{l}\text { OSA, stroke and } \\
\text { hypertension }\end{array}$ & $\begin{array}{l}225 \text { (intervention: } \\
\text { 110; control: 115) }\end{array}$ & $\begin{array}{l}\text { Auto-titrating CPAP } \\
\text { for } 1 \text { year. }\end{array}$ & $\begin{array}{l}\text { CPAP improved OSA but did } \\
\text { not lower blood pressure } \\
\text { compared with control }(-1.1 \\
\text { mmHg, } 95 \% \text { CI: }-4.2 \text { to } 2.0) \text {. }\end{array}$ \\
\hline $\begin{array}{l}\text { Minnerup } \\
\text { et al [76] }\end{array}$ & $\begin{array}{l}\text { Randomized, } \\
\text { open-label, } \\
\text { parallel-group } \\
\text { trial }\end{array}$ & $\begin{array}{l}\text { OSA, acute } \\
\text { ischemic stroke }\end{array}$ & $\begin{array}{l}50 \text { (intervention: } \\
25 \text {; control: } 25 \text { ) }\end{array}$ & $\begin{array}{l}\text { CPAP on the } 1^{\text {st }} \text { night } \\
\text { after stroke onset for } 3 \\
\text { nights; Another } 4 \\
\text { nights of CPAP were } \\
\text { added if AHI was over } \\
\text { 10/hour. }\end{array}$ & $\begin{array}{l}\text { CPAP was practicable on the } \\
1^{\text {st }} \text { night of stroke and did not } \\
\text { aggravate the outcome } \\
\text { (reduced AHI: } 32.2 \pm 25.3 \text { to } \\
9.8 \pm 6.6 \text { ). }\end{array}$ \\
\hline $\begin{array}{l}\text { Knot et al } \\
\text { [74] }\end{array}$ & $\begin{array}{l}\text { Pilot } \\
\text { randomized, } \\
\text { double-blind, } \\
\text { sham- } \\
\text { controlled trial }\end{array}$ & $\begin{array}{l}\text { OSA, stroke in } \\
\text { the rehabilitation }\end{array}$ & $\begin{array}{l}\text { Final } 30 \\
\text { (intervention: } 13 \text {; } \\
\text { sham control: } 17 \text { ) }\end{array}$ & $\begin{array}{l}\text { Active CPAP use for } \\
\text { median } 14 \text { days. }\end{array}$ & $\begin{array}{l}\text { A benefit trend of CPAP was } \\
\text { found in stroke recovery } \\
\text { (median change in FIM: } 34 \\
\text { versus } 26, p=0.25 \text { ). }\end{array}$ \\
\hline $\begin{array}{l}\text { Bravata et } \\
\text { al [75] }\end{array}$ & $\begin{array}{l}\text { Randomized } \\
\text { controlled trial }\end{array}$ & $\begin{array}{l}\text { OSA, acute } \\
\text { ischemic stroke } \\
\text { and TIA }\end{array}$ & $\begin{array}{l}252 \text { (control: } 84 \\
\text { standard: } 86 ; \\
\text { enhanced: } 82 \text { ) }\end{array}$ & $\begin{array}{l}\text { CPAP on average } 50 \% \\
\text { of nights, similar } \\
\text { among standard and } \\
\text { enhanced patients over } \\
1 \text { year. }\end{array}$ & $\begin{array}{l}\text { CPAP improved neurological } \\
\text { functions in patients with } \\
\text { OSA and acute cerebral } \\
\text { ischemia/TIA (mRS: } 33 \\
\text { versus } 19 \text { versus } 28 \text {; NIHSS: } \\
32 \text { versus } 19 \text { versus } 27 \text { ). }\end{array}$ \\
\hline $\begin{array}{l}\text { Parra et al } \\
\text { [77] }\end{array}$ & $\begin{array}{l}\text { Prospective, } \\
\text { randomized } \\
\text { controlled and } \\
\text { multi-centre } \\
\text { study }\end{array}$ & $\begin{array}{l}\text { OSA, ischemic } \\
\text { stroke }\end{array}$ & $\begin{array}{l}\text { Final } 126 \\
\text { (intervention: } 57 \text {; } \\
\text { control: } 69 \text { ) }\end{array}$ & $\begin{array}{l}\text { Nasal CPAP treated for } \\
2 \text { years and measured } \\
\text { at } 1,3,12 \text {, and } 24 \\
\text { months. }\end{array}$ & $\begin{array}{l}\text { Early CPAP use accelerated } \\
\text { recovery but did not improve } \\
\text { their survival or life quality } \\
\text { (Rankin scale: OR: } 7.78 ; 95 \% \\
\text { CI: } 1.73 \text { to } 39.84 \text { ). }\end{array}$ \\
\hline $\begin{array}{l}\text { Gupta et } \\
\text { al [78] }\end{array}$ & $\begin{array}{l}\text { Randomized, } \\
\text { parallel group } \\
\text { trial }\end{array}$ & OSA, stroke & $\begin{array}{l}\text { Final } \\
70 \text { (intervention: } \\
\text { 30; control: 40) }\end{array}$ & $\begin{array}{l}\text { Post-titration nightly } \\
\text { CPAP treatment, } \\
\text { following up } 3,6 \text {, and } \\
12 \text { months. }\end{array}$ & $\begin{array}{l}\text { CPAP group had better stroke } \\
\text { outcomes but without a } \\
\text { significant difference in the } \\
\text { recurrence of vascular events } \\
(3.3 \% \text { versus } 15 \%, P=0.23) \text {. }\end{array}$ \\
\hline $\begin{array}{l}\text { Ryan et at } \\
\text { [69] }\end{array}$ & $\begin{array}{l}\text { Randomized, } \\
\text { open-label, } \\
\text { parallel-group } \\
\text { trial }\end{array}$ & $\begin{array}{l}\text { OSA, stroke } \\
\text { patients in } \\
\text { rehabilitation } \\
\text { units }\end{array}$ & $\begin{array}{l}\text { Final } 44 \\
\text { (intervention: } 22 \text {; } \\
\text { control: } 22 \text { ) }\end{array}$ & $\begin{array}{l}\text { At least } 6 \text { hours of } \\
\text { CPAP per night for } 4 \\
\text { weeks. }\end{array}$ & $\begin{array}{l}\text { CPAP improved motor } \\
\text { function but not cognitive } \\
\text { outcomes compared with } \\
\text { baseline (SART: } \mathrm{P}=0.21 \\
\text { versus } \mathrm{P}=0.32 \text { ). }\end{array}$ \\
\hline
\end{tabular}




\begin{tabular}{|c|c|c|c|c|c|}
\hline $\begin{array}{l}\text { Sandberg } \\
\text { et al [71] }\end{array}$ & $\begin{array}{l}\text { Randomized } \\
\text { controlled trial }\end{array}$ & $\begin{array}{l}\text { Sleep apnoea, } 2- \\
4 \text { weeks post- } \\
\text { stroke }\end{array}$ & $\begin{array}{l}\text { Final } 59 \\
\text { (intervention: } 31 \text {; } \\
\text { control: } 28 \text { ) }\end{array}$ & $\begin{array}{l}\text { CPAP treatment for } 4 \\
\text { weeks. }\end{array}$ & $\begin{array}{l}\text { CPAP decreased depression } \\
\text { but not delirium or cognition } \\
\text { in stroke patients with sleep } \\
\text { apnoea (MMSE: } 2.6 ; 95 \% \mathrm{CI} \text { : } \\
1.1 \text { to } 4.1) \text {. }\end{array}$ \\
\hline $\begin{array}{l}\text { Aaronson } \\
\text { et al [79] }\end{array}$ & $\begin{array}{l}\text { Randomized } \\
\text { controlled trial }\end{array}$ & $\begin{array}{l}\text { OSA, stroke } \\
\text { patients in } \\
\text { rehabilitation } \\
\text { units }\end{array}$ & $\begin{array}{l}36 \text { (intervention: } \\
20 \text {; control: } 16 \text { ) }\end{array}$ & $\begin{array}{l}\text { CPAP treatment for } 4 \\
\text { weeks, following up } \\
\text { for } 2 \text { months. }\end{array}$ & $\begin{array}{l}\text { Cognitive function was } \\
\text { improved in the CPAP group } \\
(\mathrm{P}<0.05)\end{array}$ \\
\hline $\begin{array}{l}\text { Hsu et al } \\
{[\mathbf{8 2}]}\end{array}$ & $\begin{array}{l}\text { Randomized } \\
\text { controlled } \\
\text { single-blind } \\
\text { trial }\end{array}$ & OSA, stroke & $\begin{array}{l}\text { Final } 30 \\
\text { (intervention: } 15 ; \\
\text { control: } 15 \text { ) }\end{array}$ & $\begin{array}{l}\text { CPAP treated for } 8 \\
\text { weeks, measuring at } 8 \\
\text { weeks and } 6 \text { months } \\
\text { after stroke. }\end{array}$ & $\begin{array}{l}\text { CPAP showed no benefit in } \\
\text { neurological outcomes or } \\
\text { sleepiness, and some even in } \\
\text { poorer health status }(\mathrm{P}>0.1) \text {. }\end{array}$ \\
\hline $\begin{array}{l}\text { Svatikova } \\
\text { et al [87] }\end{array}$ & $\begin{array}{l}\text { Randomized, } \\
\text { controlled, } \\
\text { crossover study }\end{array}$ & $\begin{array}{l}\text { OSA, first } 14 \\
\text { days of ischemic } \\
\text { stroke }\end{array}$ & $\begin{array}{l}18 \text { (intervention: } \\
9 \text {; control: 9) }\end{array}$ & $\begin{array}{l}\text { Positional therapy } \\
\text { (therapeutic pillow on } \\
\text { the first or second } \\
\text { night) for } 3 \text { months. }\end{array}$ & $\begin{array}{l}\text { Positional therapy reduced } \\
\text { OSA severity after ischemia } \\
\text { and improved outcomes (AHI } \\
\text { was reduced by } 19.5 \%, 95 \% \\
\text { CI: } 4.9 \% \text { to } 31.9 \% \text { ). }\end{array}$ \\
\hline $\begin{array}{l}\text { Wheeler } \\
\text { et al [85] }\end{array}$ & $\begin{array}{l}\text { Randomized, } \\
\text { controlled, } \\
\text { two-period } \\
\text { crossover study }\end{array}$ & $\begin{array}{l}\text { OSA, acute } \\
\text { ischemic stroke }\end{array}$ & $\begin{array}{l}\text { Final } 19 \\
\text { (intervention:11; } \\
\text { control: } 8 \text { ) }\end{array}$ & $\begin{array}{l}\text { Repeated measures of } \\
\text { EPAP administered } \\
\text { every other day. }\end{array}$ & $\begin{array}{l}\text { EPAP was not superior to } \\
\text { CPAP (AHI difference: }-5.43 \text {; } \\
\text { 95\% CI: }-16.6 \text { to } 5.76 \text {, } \\
\mathrm{P}=0.314 \text { ). }\end{array}$ \\
\hline $\begin{array}{l}\text { Jiang et al } \\
\text { [91] }\end{array}$ & $\begin{array}{l}\text { Randomized } \\
\text { controlled trial }\end{array}$ & $\begin{array}{l}\text { Sleep apnea, } \\
\text { ischemic stroke }\end{array}$ & $\begin{array}{l}53 \text { (intervention: } \\
29 \text {; control: } 24 \text { ) }\end{array}$ & $\begin{array}{l}\text { Mechanical ventilation } \\
\text { (NTS) in the test group } \\
\text { and CPAP in the } \\
\text { control group. }\end{array}$ & $\begin{array}{l}\text { NTS showed a better } \\
\text { prognosis of respiratory } \\
\text { function and neurological } \\
\text { recovery than CPAP (reduce } \\
\text { NIHSS and Barthel scores, } \\
\mathrm{P}<0.05 \text { ). }\end{array}$ \\
\hline
\end{tabular}

Abbreviations: AHI: apnea-hypopnea index; BSD: breathing-related sleep disorders; CI: confidence interval; CPAP: continuous positive airway pressure; EPAP: expiratory positive airway pressure; FIM: functional independence measure; mRS: modified Rankin Scale; NIHSS: national institutes of health stroke scale; NTS: nasal endotracheal suction; OR: odds ratio; OSA: obstructive sleep apnea; PSG: polysomnography; SART: sustained attention response time; TIA: transient ischemic attack.

\section{Treatment of BSDs in stroke}

Continuous positive airway pressure (CPAP) is the first choice for OSA treatment [68]. There are different reports on the outcomes of CPAP treatment on OSA. Most studies have suggested beneficial effects, particularly in sleepiness, depression, functional recovery, and recurrent events [69-72]. A home-based randomized trial on managing sleep apnea in chronic stroke patients showed that CPAP use at home improved OSA symptoms compared with non-use (Table 2) [73]. Two randomized controlled studies also proved that CPAP was superior to conventional therapies in terms of neurological recovery $[74,75]$. The results of the study by Minnerup et al showed that CPAP utilized in the first night after stroke was practicable and was not associated with worsened outcomes [76]. Several trials supported the positive efficacy of CPAP but also pointed out some limitations. For example, Parra et al reported that early initiation with CPAP promoted recovery and postponed vascular events, but it did not improve patients' quality of life [77]. Gupta et al proved that the CPAP group displayed no apparent advantages in the recurrence of vascular events despite its favorable stroke prognosis [78]. Ryan indicated that CPAP treatment improved motor function but not neurological cognition, and Sandberg suggested that CPAP therapy did not aggravate cognitive decline in stroke patients [69, 71]. Contrary to these results mentioned above, Aaronson et.al believed that CPAP treatment improved cognitive function in stroke patients with OSA [79]. The distinction was possibly due to the CPAP treatment duration, which needs further standardization. Other investigations indicated no evident differences in the outcome, but some beneficial aspects of CPAP such as daytime wakefulness and low recurrent stroke rates were mentioned [80, 81]. However, reports from Hsu et al suggested that CPAP treatment could not improve stroke outcomes or sleepiness, and in some cases, even worsened health conditions [82].

Due to the increasingly positive evidence on CPAP therapy, the American Heart Association stated that CPAP should be applied to individuals with cerebral ischemia and TIA accompanied by OSA [83]. Consistent with the suggestion mentioned above, one recent analysis of CPAP intervention suggested that once CPAP treatment was tolerated, it was acceptable after stroke, strengthening its advantageous position for brain recovery [84]. However, less than half of patients could tolerate the device [10]. Expiratory positive airway pressure (EPAP) showed better compliance but was reported to be no better 
than CPAP in terms of treatment effects [85]. Symptoms such as severe swallowing disorders, depression, and dementia problems in patients could help to increase their CPAP compliances [86].

Though not systematically examined, weight loss should improve OSA. Weight loss could reduce the apnea-hypopnea index (AHI), which is determined by the sums of hypopnea and apnea presented during sleeping times [10]. OSA severity can be judged by the AHI and over 30 events of apnea/hypopnea in one hour should be diagnosed as severe OSA [51]. Svatikova suggested that random positional therapy (therapeutic pillow) after stroke led to a reduced AHI compared with no positional therapy [87]. Another first-line treatment is changing lifestyles such as physical activity and dieting. Keeping records of sleep information daily for 14 days was recommended for patients having difficulty falling or staying asleep [10, 51]. Moreover, preventing and treating secondary complications such as pain and respiratory infections should always be included in patient management. Drugs such as depressants and substances including ethanol should be used cautiously due to their harmful effects on sleep breathing.

As a second-line therapy, surgical treatment is reasonable for patients unable to tolerate CPAP. Surgical methods mainly include hypoglossal nerve stimulation (HNS), upper Cairway surgery, nasal reconstruction, and mandibular advancement $[88,89]$. One trial revealed that in contrast with CPAP and placebo, the surgery group showed a beneficial tendency in life and sleep quality, though without significant differences [90]. A randomized trial from Jiang et al showed that nasal endotracheal suction exhibited better breathing function and brain recovery than CPAP [91]. However, one opposite finding was that no obvious improvement after surgery compared with CPAP [92]. Randomized clinical trials of treatments of OSA after stroke are illustrated in Table 2, and further investigations are required due to the limited evidence of the effect of therapy of OSA after stroke.

Until now, published randomized trials of CSA treatment were mainly performed in patients with heart disease. Bradley et al reported that CPAP treatment alleviated CSA and cardiac functions but did not improve survival in heart failure [93]. Cowie et al reported that adaptive servo-ventilation (ASV) was useless in the recovery of heart failure or was even associated with increased mortality [94]. Another trial showed that ASV used in patients with CSA and systolic cardiac failure did not affect heart function [95]. By biphasic positive airway pressure (BiPAP) treatment, Noda et al found that patients with dilated cardiomyopathy and CSA displayed favorite outcomes on left ventricular function [96]. For the treatment of CSA after stroke, despite few randomized clinical trials, we found some reports. One retrospective analysis indicated that patients with brain ischemia receiving CPAP or BiPAP treatments failed to control CSA expectantly. When they were switched to the ASV therapy, beneficial outcomes appeared [97]. Other results also suggested that CPAP might not be the best choice in stroke patients with hypocapnic CSA and that ASV could be helpful in normocapnic CSA. However, for patients with hypercapnic CSA or hypoventilation, mechanical ventilation should be taken into account $[65,97]$. In heart failure, patients with both OSA and CSA were treated with CPAP in some cases, but ASV was a more feasible option in the long run [98]. Whether these results could be applied to stroke patients need further research. Furthermore, some drugs (antidepressants, benzodiazepines) taken by stroke patients might negatively influence CSA and should be avoided if possible [99, 100].

\section{Parasomnias and stroke}

In the DSM-5, parasomnias include non-rapid eye movement sleep arousal disorders, nightmare disorder, RBDs, and RLS [50]. Among them, RBD and RLS are the most prevalent sleep disorders associated with stroke.

For patients with RBD, they play dreams into real actions during REM sleep with their muscle tension lost and phasic muscle activities elevated. Patients with RBD might suffer from neurodegenerative diseases, and these populations are prone to suffer from stroke later on, suggesting a correlation between RBD and stroke. A cohort study including 12,003 participants showed that probable RBD was associated with a higher risk of developing stroke (both cerebral ischemia and hemorrhage), suggesting that RBD was a neglected stroke risk factor. Increased vascular stress due to sympathetic overactivity might be one of neurobiological mechanisms [101]. One observational study of 119 patients with brain ischemia reported that the RBD prevalence was approximately $11 \%$. It was reported that about $46 \%$ of RBD patients suffered from brainstem infarcts. Patients with RBD displayed a higher likelihood and proportion of acute brainstem infarct than those without RBD, suggesting that brainstem may be the primary lesion position in stroke patients with RBD [102]. RLS is characterized by an impulsion to exercise the limbs. Patients feel comfortable when doing some activities. However, at rest or at night, their symptoms are worsened. The main complaint of RLS is its abnormal sense of dragging, itching, formication, or pain. RLS has been reported to be correlated to diabetes, Parkinson's disease, iron deficiency, and terminal kidney disease, and has a tendency of autosomal-dominant transmission [10]. Studies have shown that RLS can induce insomnia and is 
often accompanied by periodic limb movements during sleep (PLMS), which involve periodically repeated moving limb involuntarily during NREM sleep [103, 104]. Transiently activated sympathetic nerves are increased in patients with RLS-related PLMS. In these patients, sleep quality declined. Whether the autonomic reaction can trigger high blood pressure should be investigated [22]. RLS occurs in about $12 \%$ of post-stroke patients. Among them, $30 \%$ have unilateral RLS symptoms, and $70 \%$ have bilateral symptoms [104]. In stroke patients, PLMS is a more frequent symptom than RLS. Stroke-related RLS primarily involves the basal ganglia. The body of the caudate nucleus is damaged, which increases dopaminergic tone and leads to RLS [105]. One case report showed that RLS appeared after the right lenticulostriate region infarction, suggesting a role of subcortical regions such as the basal ganglia-brainstem system in the regulation of motor behaviors and awake- sleep states $[104,106]$. Based on two cohort studies with a follow-up period of over 8 years, risk factors for stroke such as high blood pressure predicted RLS events, followed by further stroke occurrence in larger studies [107, 108]. Patients with RLS had thicker necks, higher diabetes prevalence and poorer sleep quality than stroke patients without RLS [103]. Furthermore, stroke recovery was undesirable in the RLS group by evaluation of the modified Rankin scale and Barthel Index. Though RLS has been proven to be related to stroke prevalence, we could not determine a causative relationship between RLS and stroke [109]. A study of 346 stroke patients showed that RLS could predict subcortical stroke, suggesting a potential role as a stroke risk factor [110]. Since available evidence is inadequate to unveil the exact correlation between RLS and stroke, more conclusive studies are pressingly needed.

Table 3. Neurobiological mechanisms of current treatments and their effects on stroke.

\begin{tabular}{|c|c|c|c|}
\hline $\begin{array}{l}\text { Sleep } \\
\text { disorder }\end{array}$ & Treatment & Biological mechanisms & Effects on stroke \\
\hline \multirow[t]{5}{*}{ Insomnia } & CBT & $\begin{array}{l}\text { Decreasing dysfunctional beliefs and } \\
\text { attitudes [134] }\end{array}$ & $\begin{array}{l}\text { Effective in patients with post-stroke } \\
\text { depression [135] }\end{array}$ \\
\hline & BZD & $\begin{array}{l}\text { Hypnotic and sedative effects by binding to } \\
\text { GABAA to lower neural excitability, but }_{\text {aggravate OSA [136] }}\end{array}$ & $\begin{array}{l}\text { Both neuroprotection (low dosage) and } \\
\text { neurotoxicity (high dosage) [36] }\end{array}$ \\
\hline & Mianserin & $\begin{array}{l}\text { Tetracyclic antidepressant and anxiolytic } \\
\text { effects by antagonizing histamine and } \\
\text { serotonin receptors }[137,138]\end{array}$ & $\begin{array}{l}\text { Delaying neuronal death on ischemic } \\
\text { stroke animal model }[139,140]\end{array}$ \\
\hline & Zolpidem & $\begin{array}{l}\text { Hypnotic by inhibiting GABA receptor }[141 \text {, } \\
142]\end{array}$ & $\begin{array}{l}\text { Increasing BDNF secretion and protecting } \\
\text { the neurovascular unit in acute stroke but } \\
\text { harmful at high doses [35] }\end{array}$ \\
\hline & Acupuncture & $\begin{array}{l}\text { Reducing the sympathetic nervous activity } \\
\text { [38] }\end{array}$ & $\begin{array}{l}\text { Debatable influence on stroke } \\
\text { rehabilitation, warrant further studies [143, } \\
144]\end{array}$ \\
\hline \multirow[t]{3}{*}{ Hypersomnia } & Modafinil & $\begin{array}{l}\text { Weak dopamine re-uptake inhibitor to } \\
\text { promote awakening [145] }\end{array}$ & $\begin{array}{l}\text { Reducing fatigue and improved quality of } \\
\text { life after stroke [146] }\end{array}$ \\
\hline & Methylphenidate & $\begin{array}{l}\text { A norepinephrine-dopamine reuptake } \\
\text { inhibitor and neurological stimulant [147] }\end{array}$ & $\begin{array}{l}\text { Improving ischemic stroke recovery } \\
\text { slightly [148] }\end{array}$ \\
\hline & Levodopa & $\begin{array}{l}\text { A precursor of the dopamine, modulating } \\
\text { sleep-wake state [22] }\end{array}$ & $\begin{array}{l}\text { Improving functional recovery after stroke } \\
{[149]}\end{array}$ \\
\hline \multirow[t]{3}{*}{ OSA } & CPAP/EPAP & $\begin{array}{l}\text { Improving obstructive breathing and hypoxia } \\
\text { state }[150]\end{array}$ & $\begin{array}{l}\text { Generally beneficial outcomes for stroke } \\
\text { patients }[73,77]\end{array}$ \\
\hline & $\begin{array}{l}\text { Positional } \\
\text { therapy }\end{array}$ & $\begin{array}{l}\text { Changing sleep position and ameliorate } \\
\text { hypoxia [87] }\end{array}$ & Improving stroke outcomes [87] \\
\hline & Surgery & $\begin{array}{l}\text { Airway reconstruction to benefit ventilation } \\
{[88]}\end{array}$ & Better brain recovery [91] \\
\hline CSA & $\begin{array}{l}\text { ASV/mechanical } \\
\text { ventilation }\end{array}$ & $\begin{array}{l}\text { Improving hypoventilation and maintaining } \\
\text { blood-gas balance [65] }\end{array}$ & Beneficial outcomes in stroke patients [97] \\
\hline \multirow[t]{2}{*}{ RBD } & Clonazepam & $\begin{array}{l}\text { Binding GABA receptor and inhibiting neural } \\
\text { excitability }[151]\end{array}$ & $\begin{array}{l}\text { Improving the outcome of post-stroke } \\
\text { movement disorders [152] }\end{array}$ \\
\hline & Melatonin & $\begin{array}{l}\text { Activating melatonin receptor to decrease } \\
\text { violent attacks and improve dream enactment } \\
{[21]}\end{array}$ & Brain protection after stroke $[153,154]$ \\
\hline
\end{tabular}




\begin{tabular}{llll} 
& Fluoxetine & $\begin{array}{l}\text { Inhibiting serotonin re-uptake and playing } \\
\text { antidepressant effect [155] }\end{array}$ & $\begin{array}{l}\text { Enhancing motor recovery in ischemic } \\
\text { stroke [156, 157] }\end{array}$ \\
\hline RLS & $\begin{array}{l}\text { Levodopa and } \\
\text { dopamine } \\
\text { agonists }\end{array}$ & $\begin{array}{l}\text { Activating dopaminergic pathway and } \\
\text { regulating extrapyramidal system [158] }\end{array}$ & $\begin{array}{l}\text { Improving functional recovery after stroke } \\
{[149]}\end{array}$
\end{tabular}

Gabapentin Inhibiting voltage-dependent calcium channels, improving sensory and motor symptoms $[159,160]$
Neuroprotection, seizure and neuralgia suppression after stroke [161, 162]

Abbreviations: ASV: adaptive servo-ventilation; BDNF: brain-derived neurotrophic factor; BZD: Benzodiazepines; CBT: cognitive-behavioral therapy; CPAP: continuous positive airway pressure; CSA: central sleep apnea; EPAP: expiratory positive airway pressure; GABA: gammaaminobutyric acid; OSA: obstructive sleep apnea; RBD: rapid eye movement sleep behavior disorder; RLS: insomnia and restless leg syndrome.

\section{Treatments of RBD and RLS in stroke}

First and foremost, both injury prevention and prognostic counseling should be included in RBD management. Currently, primary and secondary RBD are treated similarly. The results from one case report showed that symptoms were relieved by clonazepam in 2 patients with RBD after stroke [30]. Doses of clonazepam ranging from 0.25-2.0 $\mathrm{mg}$ were reported to be effective for treating stroke patients with RBD [21, 30]. In addition to clonazepam, melatonin can decrease violent attacks and improve dream enactment. Fluoxetine was also effective in stroke-associated RBD but was reported merely in one individual with syncope [111]. Medications including alcohol, stimulants, SSRIs, and selegiline worsened RBD and should be avoided. Since most proof is based on case reports, reliable randomized clinical studies on pharmacotherapy should be emphasized in the next step.

It is well established that levodopa, dopamine agonists (pramipexole and ropinirole) and gabapentin can be used to treat stroke-related RLS/PLMS patients [104]. In general, dopamine agonists, though associated with more side effects, played more effective roles than levodopa, since significant relief was reported in most patients taking dopamine agonists. In addition, the rate of spontaneous improvement observed was approximately $25 \%$, indicating that some patients can go without pharmacotherapy [21, 112]. Iron supplementation is an important step of treatment in patients with iron deficiency. Several drugs including antidepressants and diazepam should be used with caution due to their adverse effects on RLS. The neurobiological mechanisms of current treatments and their effects on stroke are summarized in Table 3.

As the primary subtype of stroke, ischemic stroke is the most commonly researched cerebrovascular disease together with sleep disorders. However, there were no significant differences in the frequency of sleep disorders among patients with cerebral ischemia and hemorrhage. Moreover, sleep disturbances were slightly more frequent in hemorrhagic stroke [113]. One large population-based study including 95,023 adults showed that sleep duration over 8 hours was closely associated with cerebral hemorrhage in women. Men who slept over 10 hours had a tendency of higher mortality of hemorrhagic stroke [114]. Furthermore, OSA was reported in a patient with intracerebral hemorrhage [115]. Sleep and wake disorders were also found in patients after subarachnoid hemorrhage [116]. For RBD, deposition of $\alpha$-synuclein could be related to amyloid angiopathy and intracerebral hematoma formation, suggesting that RBD increased the risk of hemorrhagic stroke [101]. Similarly, unilateral or asymmetrical RLS might pre-exist in patients with subcortical hemorrhage, suggesting its predictive value for hemorrhagic stroke [110]. Taken together, a body of evidence suggests that sleep disorders are strongly related to not only ischemic but also hemorrhagic stroke events. In other words, sleep disorders play roles as both risk factors for and complications of hemorrhagic stroke [117]. Therefore, hemorrhagic stroke patients should be paid the same attention as ischemic stroke patients, and proper management should be performed in the long run.

\section{Sleep disorders and post-stroke depression (PSD)}

As one mental complication of stroke, depression has been the focus of research and received more attention than other complications such as anxiety. PSD usually presents during two ranges after stroke: one between 3-6 months and the other between 2-3 years after stroke [118]. With the same clinical manifestations of traditional depression, PSD is mainly characterized by mood dysfunctions including depressive feelings, indifference, irritability, and vegetative signs including sleep disorders $[119,120]$. Despite the similarity to other depressed patients with atherosclerotic diseases, the symptoms of depression were more severe in patients with PSD than in those with atherosclerotic diseases [121]. It was recorded that the number of patients currently being examined for PSD was over 7,000 and that the prevalence of PSD was about $30 \%$ in stroke survivors $[122,123]$. The percentage fluctuated with the research population, depression severity, and follow-up durations enrolled by researchers. Though prevalent, PSD was often underestimated, and 
some patients remained unrecognized and untreated, which further increased the morbidity. Studies have revealed that PSD predicts mortality and is connected with stroke occurrence and recovery $[124,125]$.

One cross-sectional study examined the connection between sleep and PSD. It was found that PSD was correlated with poor sleep quality and subjective parameters of sleep [126]. Another research on elderly patients in China showed that neural dysfunction and insomnia were related to PSD [127]. For patients with PSD in the acute phase of stroke, sleep disorders were common but nonspecific, and fatigue and inappetence might be key predictors of PSD [118]. Hence, for stroke patients, PSD and sleep disorders are closely interrelated with each other and must be actively treated together.

Since the treatments of sleep disorders after stroke are mentioned above, immediate therapy for PSD is very helpful for improving long-term recovery of stroke as well as sleep disturbances after stroke. One survey found that patients with PSD taking antidepressants from the first month of stroke presented more improvement in daily living activities than those taking antidepressants after one month of stroke. Furthermore, the early-used group maintained alleviated symptoms for up to 2 years. This finding indicated that early treatment of PSD was related to improvement in physical activities and stroke recovery [128]. For PSD therapy, it was recommended to use antidepressants such as SSRIs, which could improve depression with time $[129,130]$. In addition to SSRIs (such as citalopram), nortriptyline and reboxetine have also been widely researched, but their contraindications and plasma concentrations should be carefully noted [122]. Considering the intricate complications of stroke individuals, optimal balances between the benefits and adverse effects of drugs are needed. Other methods such as CBT, electroconvulsive therapy, and psychological treatments are promising but need more evidence [122, 131].

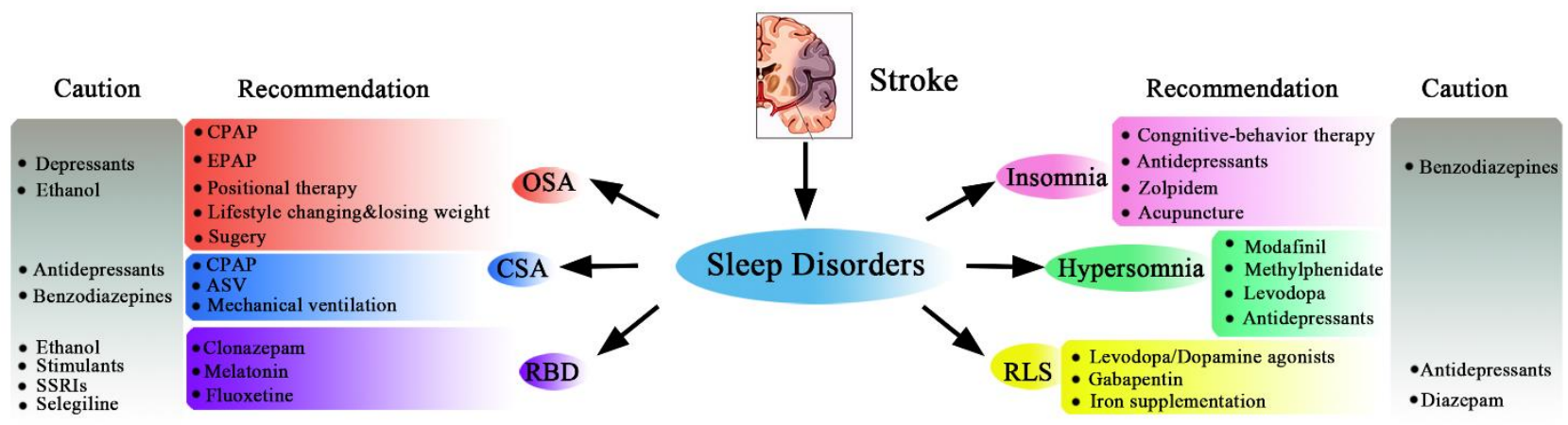

Figure 1. Summary of therapeutic recommendations and cautions of sleep disorders after stroke. ASV: adaptive servoventilation; CPAP: continuous positive airway pressure; CSA: central sleep apnea; EPAP: expiratory positive airway pressure; OSA: obstructive sleep apnea; SSRIs: selective serotonin reuptake inhibitors; RBD: rapid eye movement sleep behavior disorder; RLS: restless leg syndrome.

\section{Future perspectives and conclusion}

To date, scientists have explored different types of sleep disorders in stroke and have put forward potential treatment strategies for them as well as pitfalls of these treatments (Fig. 1). However, unresolved questions still exist. Research on sleep disorders in animal models of stroke can help us further deeply understand how the brain functions to control sleep and wake since basic research is revealing more pathophysiological mechanisms underlying sleep disorders and intricate relationships between stroke and sleep processes. It has been proven that stroke related-sleep disturbances negatively regulate angiogenesis, axonal sprouting and synaptogenesis, aggravate brain damage and ultimately hinder neurological recovery $[28,132]$. However, from clinical perspectives, there is still limited literature researching the causal relationships between specific sleep disorders and stroke recovery although sleep disorders remain as both a risk factor for and poor outcome of stroke [68]. Meanwhile, more attention should be paid to large randomized controlled trials of post-stroke sleep disturbances such as hypersomnia, RLS and RBD. Moreover, detailed investigations on the correlations of sleep disorders and PSD, their treatments and possible prognosis are pressingly needed.

In conclusion, we focused on specific therapeutic interventions of sleep disorders in stroke. Briefly, OSA treatment with CPAP is recommended in view of increasingly supportive proof. Oxygen, ASV, or noninvasive ventilation may be considered in patients with CSA after stroke. Treatments of insomnia with sedative 
antidepressants, hypersomnia with stimulants, RLS with dopaminergic drugs, and RBD with clonazepam are based on limited reports and should be adopted individually. Behavioral-neuropsychological therapy and other supporting therapies such as acupuncture are promising but need more convincing evidence. Furthermore, sleep disorders with PSD should also be emphasized and treated properly. In the future, we confidently believe that sleep disorders in stroke patients will be paid more attention to and that more individualized and evidence-based management will be developed.

\section{Acknowledgments}

This study had been supported by the grant of the National Nature Science Foundation of China (81671251\#).

\section{Conflict of interest}

The authors declare no conflict of interest, financial or otherwise.

\section{References}

[1] St-Onge MP, Grandner MA, Brown D, Conroy MB, Jean-Louis G, Coons M, et al. (2016). Sleep Duration and Quality: Impact on Lifestyle Behaviors and Cardiometabolic Health: A Scientific Statement From the American Heart Association. Circulation, 134:e367-e386.

[2] Plante DT (2019). The Importance of Sleep Phenotypes in Bipolar Disorders. JAMA Psychiatry.

[3] Eugene AR, Masiak J (2015). The Neuroprotective Aspects of Sleep. MEDtube Sci, 3:35-40.

[4] Chennaoui M, Leger D, Gomez-Merino D (2020). Sleep and the GH/IGF-1 axis: Consequences and countermeasures of sleep loss/disorders. Sleep Med Rev, 49:101223.

[5] Muth CC (2016). Sleep-Wake Disorders. JAMA, 316:2322.

[6] Sateia MJ (2014). International classification of sleep disorders-third edition: highlights and modifications. Chest, 146:1387-1394.

[7] Sivertsen B, Pallesen S, Friborg O, Nilsen KB, Bakke OK, Goll JB, et al. (2020). Sleep patterns and insomnia in a large population-based study of middle-aged and older adults: The Tromso study 2015-2016. J Sleep Res:e13095.

[8] Santamaria J, Iranzo A (2014). Sleep disorders matter in neurology. Lancet Neurol, 13:18-20.

[9] Baril AA, Gagnon JF, Pelletier A, Soucy JP, Gosselin N, Postuma RB, et al. (2020). Changes in Regional Cerebral Perfusion Over Time in Idiopathic REM Sleep Behavior Disorder. Mov Disord.

[10] Yaremchuk K (2018). Sleep Disorders in the Elderly. Clin Geriatr Med, 34:205-216.
[11] Maaijwee NA, Rutten-Jacobs LC, Schaapsmeerders P, van Dijk EJ, de Leeuw FE (2014). Ischaemic stroke in young adults: risk factors and long-term consequences. Nat Rev Neurol, 10:315-325.

[12] Hill VA, Towfighi A (2017). Modifiable Risk Factors for Stroke and Strategies for Stroke Prevention. Semin Neurol, 37:237-258.

[13] Feigin VL, Norrving B, Mensah GA (2017). Global Burden of Stroke. Circ Res, 120:439-448.

[14] Hankey GJ (2017). Stroke. Lancet, 389:641-654.

[15] Hankey GJ, Blacker DJ (2015). Is it a stroke? BMJ, 350:h56.

[16] Amarenco P, Bogousslavsky J, Caplan LR, Donnan GA, Hennerici MG (2009). Classification of stroke subtypes. Cerebrovasc Dis, 27:493-501.

[17] de Montmollin E, Terzi N, Dupuis C, Garrouste-Orgeas M, Silva D, Darmon M, et al. (2020). One-year survival in acute stroke patients requiring mechanical ventilation: a multicenter cohort study. Annals of Intensive Care, 10.

[18] Nedeltchev K, der Maur TA, Georgiadis D, Arnold M, Caso V, Mattle HP, et al. (2005). Ischaemic stroke in young adults: predictors of outcome and recurrence. $\mathbf{J}$ Neurol Neurosurg Psychiatry, 76:191-195.

[19] Xie X, Atkins E, Lv J, Bennett A, Neal B, Ninomiya T, et al. (2016). Effects of intensive blood pressure lowering on cardiovascular and renal outcomes: updated systematic review and meta-analysis. Lancet, 387:435-443.

[20] Feigin VL, Roth GA, Naghavi M, Parmar P, Krishnamurthi R, Chugh S, et al. (2016). Global burden of stroke and risk factors in 188 countries, during 19902013: a systematic analysis for the Global Burden of Disease Study 2013. Lancet Neurol, 15:913-924.

[21] Hermann DM, Bassetti CL (2016). Role of sleepdisordered breathing and sleep-wake disturbances for stroke and stroke recovery. Neurology, 87:1407-1416.

[22] Hermann DM, Bassetti CL (2009). Sleep-related breathing and sleep-wake disturbances in ischemic stroke. Neurology, 73:1313-1322.

[23] Baylan S, Griffiths S, Grant N, Broomfield NM, Evans JJ, Gardani M (2020). Incidence and prevalence of poststroke insomnia: A systematic review and metaanalysis. Sleep Medicine Reviews, 49.

[24] Mims KN, Kirsch D (2016). Sleep and Stroke. Sleep Med Clin, 11:39-51.

[25] Koenigs M, Holliday J, Solomon J, Grafman J (2010). Left dorsomedial frontal brain damage is associated with insomnia. J Neurosci, 30:16041-16043.

[26] Leng Y, Cappuccio FP, Wainwright NW, Surtees PG, Luben R, Brayne C, et al. (2015). Sleep duration and risk of fatal and nonfatal stroke: a prospective study and meta-analysis. Neurology, 84:1072-1079.

[27] Wu MP, Lin HJ, Weng SF, Ho CH, Wang JJ, Hsu YW (2014). Insomnia Subtypes and the Subsequent Risks of Stroke Report From a Nationally Representative Cohort. Stroke, 45:1349-1354.

[28] Zunzunegui C, Gao B, Cam E, Hodor A, Bassetti CL (2011). Sleep disturbance impairs stroke recovery in the rat. Sleep, 34:1261-1269. 
[29] Hodor A, Palchykova S, Gao B, Bassetti CL (2015). Baclofen and gamma-hydroxybutyrate differentially altered behavior, EEG activity and sleep in rats. Neuroscience, 284:18-28.

[30] Duss SB, Brill AK, Bargiotas P, Facchin L, Alexiev F, Manconi M, et al. (2018). Sleep-Wake Disorders in Stroke-Increased Stroke Risk and Deteriorated Recovery? An Evaluation on the Necessity for Prevention and Treatment. Curr Neurol Neurosci Rep, 18:72.

[31] Nguyen S, Wong D, McKay A, Rajaratnam SMW, Spitz G, Williams G, et al. (2019). Cognitive behavioural therapy for post-stroke fatigue and sleep disturbance: a pilot randomised controlled trial with blind assessment. Neuropsychol Rehabil, 29:723-738.

[32] Palomaki H, Berg A, Meririnne E, Kaste M, Lonnqvist R, Lehtihalmes M, et al. (2003). Complaints of poststroke insomnia and its treatment with mianserin. Cerebrovasc Dis, 15:56-62.

[33] Kim JS, Lee EJ, Chang DI, Park JH, Ahn SH, Cha JK, et al. (2017). Efficacy of early administration of escitalopram on depressive and emotional symptoms and neurological dysfunction after stroke: a multicentre, double-blind, randomised, placebo-controlled study. Lancet Psychiatry, 4:33-41.

[34] Hiu T, Farzampour Z, Paz JT, Wang EH, Badgely C, Olson A, et al. (2016). Enhanced phasic GABA inhibition during the repair phase of stroke: a novel therapeutic target. Brain, 139:468-480.

[35] Oh MK, Yoon KJ, Lee YT, Chae SW, Choi HY, Shin HS, et al. (2018). Effect of zolpidem on functional recovery in a rat model of ischemic stroke. J Int Med Res, 46:249-257.

[36] Huang WS, Muo CH, Chang SN, Chang YJ, Tsai CH, $\mathrm{Kao} \mathrm{CH}$ (2014). Benzodiazepine use and risk of stroke: a retrospective population-based cohort study. Psychiatry Clin Neurosci, 68:255-262.

[37] Kim YS, Lee SH, Jung WS, Park SU, Moon SK, Ko $\mathrm{CN}$, et al. (2004). Intradermal acupuncture on shen-men and nei-kuan acupoints in patients with insomnia after stroke. Am J Chin Med, 32:771-778.

[38] Lee SY, Baek YH, Park SU, Moon SK, Park JM, Kim YS, et al. (2009). Intradermal acupuncture on shen-men and nei-kuan acupoints improves insomnia in stroke patients by reducing the sympathetic nervous activity: a randomized clinical trial. Am J Chin Med, 37:10131021.

[39] Lee SH, Lim SM (2016). Acupuncture for insomnia after stroke: a systematic review and meta-analysis. BMC Complement Altern Med, 16:228.

[40] Tang L, Ma C, You F, Ding L (2015). [Impacts of the low-frequency electric stimulation at the acupoints on the content of plasma 5-HT and NE in the patients with post-stroke insomnia]. Zhongguo Zhen Jiu, 35:763-767.

[41] Hou Z, Sun Z, Sun S (2018). [Impacts of the repetitive transcranial acupuncture stimulation on the content of serum orexin A in patients with post-stroke insomnia]. Zhongguo Zhen Jiu, 38:1039-1042.

[42] Hermann DM, Siccoli M, Brugger P, Wachter K, Mathis J, Achermann P, et al. (2008). Evolution of neurological, neuropsychological and sleep-wake disturbances after paramedian thalamic stroke. Stroke, 39:62-68.

[43] Bin Im K, Strader S, Dyken ME (2010). Management of Sleep Disorders in Stroke. Current Treatment Options in Neurology, 12:379-395.

[44] Bassetti C, Mathis J, Gugger M, Lovblad KO, Hess CW (1996). Hypersomnia following paramedian thalamic stroke: a report of 12 patients. Ann Neurol, 39:471-480.

[45] Harris AL, Elder J, Schiff ND, Victor JD, Goldfine AM (2014). Post-Stroke Apathy and Hypersomnia Lead to Worse Outcomes from Acute Rehabilitation. Translational Stroke Research, 5:292-300.

[46] Koo DL, Nam H, Thomas RJ, Yun CH (2018). Sleep Disturbances as a Risk Factor for Stroke. Journal of Stroke, 20:12-32.

[47] Ramos AR, Dong C, Rundek T, Elkind MS, BodenAlbala B, Sacco RL, et al. (2014). Sleep duration is associated with white matter hyperintensity volume in older adults: the Northern Manhattan Study. J Sleep Res, 23:524-530.

[48] Harris AL, Elder J, Schiff ND, Victor JD, Goldfine AM (2014). Post-stroke apathy and hypersomnia lead to worse outcomes from acute rehabilitation. Transl Stroke Res, 5:292-300.

[49] West A, Simonsen SA, Jennum P, Cyril Hansen N, Schonsted M, Zielinski A, et al. (2019). An exploratory investigation of the effect of naturalistic light on fatigue and subjective sleep quality in stroke patients admitted for rehabilitation: A randomized controlled trial. NeuroRehabilitation, 45:187-200.

[50] Reynolds CF, 3rd, O'Hara R (2013). DSM-5 sleep-wake disorders classification: overview for use in clinical practice. Am J Psychiatry, 170:1099-1101.

[51] Parasram M, Segal AZ (2019). Sleep Disorders and Stroke: Does Treatment of Obstructive Sleep Apnea Decrease Risk of Ischemic Stroke? Curr Treat Options Neurol, 21:29.

[52] Birkbak J, Clark AJ, Rod NH (2014). The effect of sleep disordered breathing on the outcome of stroke and transient ischemic attack: a systematic review. J Clin Sleep Med, 10:103-108.

[53] Bassetti CL, Milanova M, Gugger M (2006). Sleepdisordered breathing and acute ischemic stroke: diagnosis, risk factors, treatment, evolution, and longterm clinical outcome. Stroke, 37:967-972.

[54] Bassetti CLA, Randerath W, Vignatelli L, FeriniStrambi L, Brill AK, Bonsignore MR, et al. (2020). EAN/ERS/ESO/ESRS statement on the impact of sleep disorders on risk and outcome of stroke. European Journal of Neurology.

[55] Sanchez-de-la-Torre M, Campos-Rodriguez F, Barbe F (2013). Obstructive sleep apnoea and cardiovascular disease. Lancet Respir Med, 1:61-72.

[56] Yaggi HK, Concato J, Kernan WN, Lichtman JH, Brass LM, Mohsenin V (2005). Obstructive sleep apnea as a risk factor for stroke and death. $\mathrm{N}$ Engl J Med, 353:2034-2041.

[57] Dalgaard F, North R, Pieper K, Fonarow GC, Kowey PR, Gersh BJ, et al. (2020). Risk of major 
cardiovascular and neurologic events with obstructive sleep apnea among patients with atrial fibrillation. American Heart Journal, 223:65-71.

[58] Mansukhani MP, Bellolio MF, Kolla BP, Enduri S, Somers VK, Stead LG (2011). Worse outcome after stroke in patients with obstructive sleep apnea: an observational cohort study. J Stroke Cerebrovasc Dis, 20:401-405.

[59] Sandberg O, Franklin KA, Bucht G, Gustafson Y (2001). Sleep apnea, delirium, depressed mood, cognition, and ADL ability after stroke. J Am Geriatr Soc, 49:391-397.

[60] Labarca G, Saavedra D, Dreyse J, Jorquera J, Barbe F (2020). Efficacy of CPAP for Improvements in Sleepiness, Cognition, Mood, and Quality of Life in Elderly Patients With OSA: Systematic Review and Meta-analysis of Randomized Controlled Trials. Chest.

[61] Ifergane G, Ovanyan A, Toledano R, Goldbart A, AbuSalame I, Tal A, et al. (2016). Obstructive Sleep Apnea in Acute Stroke: A Role for Systemic Inflammation. Stroke, 47:1207-1212.

[62] Bosch JL, Weiss JP (2013). The prevalence and causes of nocturia. J Urol, 189:S86-92.

[63] Wessendorf TE, Teschler H, Wang YM, Konietzko N, Thilmann AF (2000). Sleep-disordered breathing among patients with first-ever stroke. Journal of Neurology, 247:41-47.

[64] Rowat AM, Dennis MS, Wardlaw JM (2006). Central periodic breathing observed on hospital admission is associated with an adverse prognosis in conscious acute stroke patients. Cerebrovasc Dis, 21:340-347.

[65] Baillieul S, Revol B, Jullian-Desayes I, Joyeux-Faure M, Tamisier R, Pepin JL (2019). Diagnosis and management of central sleep apnea syndrome. Expert Rev Respir Med, 13:545-557.

[66] Javaheri S (2010). Central sleep apnea. Clin Chest Med, 31:235-248.

[67] Pajediene E, Pajeda A, Urnieziute G, Paulekas E, Liesiene V, Bileviciute-Ljungar I, et al. (2020). Subjective and objective features of sleep disorders in patients with acute ischemic or haemorrhagic stroke: It is not only sleep apnoea which is important. Medical Hypotheses, 136.

[68] Khot SP, Morgenstern LB (2019). Sleep and Stroke. Stroke, 50:1612-1617.

[69] Ryan CM, Bayley M, Green R, Murray BJ, Bradley TD (2011). Influence of continuous positive airway pressure on outcomes of rehabilitation in stroke patients with obstructive sleep apnea. Stroke, 42:1062-1067.

[70] Parra O, Sanchez-Armengol A, Capote F, Bonnin M, Arboix A, Campos-Rodriguez F, et al. (2015). Efficacy of continuous positive airway pressure treatment on 5year survival in patients with ischaemic stroke and obstructive sleep apnea: a randomized controlled trial. J Sleep Res, 24:47-53.

[71] Sandberg O, Franklin KA, Bucht G, Eriksson S, Gustafson Y (2001). Nasal continuous positive airway pressure in stroke patients with sleep apnoea: a randomized treatment study. Eur Respir J, 18:630-634.
[72] Bravata DM, Concato J, Fried T, Ranjbar N, Sadarangani T, McClain V, et al. (2011). Continuous positive airway pressure: evaluation of a novel therapy for patients with acute ischemic stroke. Sleep, 34:12711277.

[73] Bravata DM, McClain V, Austin C, Ferguson J, Burrus N, Miech EJ, et al. (2017). Diagnosing and managing sleep apnea in patients with chronic cerebrovascular disease: a randomized trial of a home-based strategy. Sleep Breath, 21:713-725.

[74] Khot SP, Davis AP, Crane DA, Tanzi PM, Lue DL, Claflin ES, et al. (2016). Effect of Continuous Positive Airway Pressure on Stroke Rehabilitation: A Pilot Randomized Sham-Controlled Trial. J Clin Sleep Med, 12:1019-1026.

[75] Bravata DM, Sico J, Vaz Fragoso CA, Miech EJ, Matthias MS, Lampert R, et al. (2018). Diagnosing and Treating Sleep Apnea in Patients With Acute Cerebrovascular Disease. J Am Heart Assoc, 7:e008841.

[76] Minnerup J, Ritter MA, Wersching H, Kemmling A, Okegwo A, Schmidt A, et al. (2012). Continuous positive airway pressure ventilation for acute ischemic stroke: a randomized feasibility study. Stroke, 43:11371139.

[77] Parra O, Sanchez-Armengol A, Bonnin M, Arboix A, Campos-Rodriguez F, Perez-Ronchel J, et al. (2011). Early treatment of obstructive apnoea and stroke outcome: a randomised controlled trial. Eur Respir J, 37:1128-1136.

[78] Gupta A, Shukla G, Afsar M, Poornima S, Pandey RM, Goyal V, et al. (2018). Role of Positive Airway Pressure Therapy for Obstructive Sleep Apnea in Patients With Stroke: A Randomized Controlled Trial. J Clin Sleep Med, 14:511-521.

[79] Aaronson JA, Hofman WF, van Bennekom CA, van Bezeij T, van den Aardweg JG, Groet E, et al. (2016). Effects of Continuous Positive Airway Pressure on Cognitive and Functional Outcome of Stroke Patients with Obstructive Sleep Apnea: A Randomized Controlled Trial. J Clin Sleep Med, 12:533-541.

[80] Bravata DM, Concato J, Fried T, Ranjbar N, Sadarangani T, McClain V, et al. (2010). Auto-titrating continuous positive airway pressure for patients with acute transient ischemic attack: a randomized feasibility trial. Stroke, 41:1464-1470.

[81] Brown DL, Chervin RD, Kalbfleisch JD, Zupancic MJ, Migda EM, Svatikova A, et al. (2013). Sleep apnea treatment after stroke (SATS) trial: is it feasible? J Stroke Cerebrovasc Dis, 22:1216-1224.

[82] Hsu CY, Vennelle M, Li HY, Engleman HM, Dennis MS, Douglas NJ (2006). Sleep-disordered breathing after stroke: a randomised controlled trial of continuous positive airway pressure. J Neurol Neurosurg Psychiatry, 77:1143-1149.

[83] Kernan WN, Ovbiagele B, Black HR, Bravata DM, Chimowitz MI, Ezekowitz MD, et al. (2014). Guidelines for the prevention of stroke in patients with stroke and transient ischemic attack: a guideline for healthcare professionals from the American Heart 
Association/American Stroke Association. Stroke, 45:2160-2236.

[84] Brill AK, Horvath T, Seiler A, Camilo M, Haynes AG, Ott SR, et al. (2018). CPAP as treatment of sleep apnea after stroke: A meta-analysis of randomized trials. Neurology, 90:e1222-e1230.

[85] Wheeler NC, Wing JJ, O'Brien LM, Hughes R, Jacobs T, Claflin E, et al. (2016). Expiratory Positive Airway Pressure for Sleep Apnea after Stroke: A Randomized, Crossover Trial. J Clin Sleep Med, 12:1233-1238.

[86] Benbir G, Karadeniz D (2012). A pilot study of the effects of non-invasive mechanical ventilation on the prognosis of ischemic cerebrovascular events in patients with obstructive sleep apnea syndrome. Neurol Sci, 33:811-818.

[87] Svatikova A, Chervin RD, Wing JJ, Sanchez BN, Migda EM, Brown DL (2011). Positional therapy in ischemic stroke patients with obstructive sleep apnea. Sleep Med, 12:262-266.

[88] Won CH, Li KK, Guilleminault C (2008). Surgical treatment of obstructive sleep apnea: upper airway and maxillomandibular surgery. Proc Am Thorac Soc, 5:193-199.

[89] Lee JHA, Byun YJ, Nguyen SA, Lentsch EJ, Gillespie MB (2020). Transoral Robotic Surgery versus Plasma Ablation for Tongue Base Reduction in Obstructive Sleep Apnea: Meta-analysis. Otolaryngology-Head and Neck Surgery, 162:839-852.

[90] Woodson BT, Steward DL, Weaver EM, Javaheri S (2003). A randomized trial of temperature-controlled radiofrequency, continuous positive airway pressure, and placebo for obstructive sleep apnea syndrome. Otolaryngol Head Neck Surg, 128:848-861.

[91] Jiang PR, Zhang N, Wu YF, Qiu ZL (2015). Effect analysis of nasotracheal suction mechanical ventilation treatment of cerebral ischemic stroke induced by sleep apnea. Eur Rev Med Pharmacol Sci, 19:1766-1772.

[92] Robinson S, Chia M, Carney AS, Chawla S, Harris P, Esterman A (2009). Upper airway reconstructive surgery long-term quality-of-life outcomes compared with CPAP for adult obstructive sleep apnea. Otolaryngol Head Neck Surg, 141:257-263.

[93] Bradley TD, Logan AG, Kimoff RJ, Series F, Morrison $\mathrm{D}$, Ferguson $\mathrm{K}$, et al. (2005). Continuous positive airway pressure for central sleep apnea and heart failure. N Engl J Med, 353:2025-2033.

[94] Cowie MR, Woehrle H, Wegscheider K, Angermann C, d'Ortho MP, Erdmann E, et al. (2015). Adaptive ServoVentilation for Central Sleep Apnea in Systolic Heart Failure. N Engl J Med, 373:1095-1105.

[95] Cowie MR, Woehrle H, Wegscheider K, Vettorazzi E, Lezius S, Koenig W, et al. (2018). Adaptive servoventilation for central sleep apnoea in systolic heart failure: results of the major substudy of SERVE-HF. Eur J Heart Fail, 20:536-544.

[96] Noda A, Izawa H, Asano H, Nakata S, Hirashiki A, Murase Y, et al. (2007). Beneficial effect of bilevel positive airway pressure on left ventricular function in ambulatory patients with idiopathic dilated cardiomyopathy and central sleep apnea-hypopnea: a preliminary study. Chest, 131:1694-1701.

[97] Brill AK, Rosti R, Hefti JP, Bassetti C, Gugger M, Ott SR (2014). Adaptive servo-ventilation as treatment of persistent central sleep apnea in post-acute ischemic stroke patients. Sleep Med, 15:1309-1313.

[98] Randerath WJ, Nothofer G, Priegnitz C, Anduleit N, Treml M, Kehl V, et al. (2012). Long-term autoservoventilation or constant positive pressure in heart failure and coexisting central with obstructive sleep apnea. Chest, 142:440-447.

[99] Lu B, Budhiraja R, Parthasarathy S (2005). Sedating medications and undiagnosed obstructive sleep apnea: physician determinants and patient consequences. J Clin Sleep Med, 1:367-371.

[100] Correa D, Farney RJ, Chung F, Prasad A, Lam D, Wong J (2015). Chronic Opioid Use and Central Sleep Apnea: A Review of the Prevalence, Mechanisms, and Perioperative Considerations. Anesthesia and Analgesia, 120:1273-1285.

[101] Ma CR, Pavlova M, Liu YS, Liu Y, Huangfu CM, Wu SL, et al. (2017). Probable REM sleep behavior disorder and risk of stroke A prospective study. Neurology, 88:1849-1855.

[102] Tang WK, Hermann DM, Chen YK, Liang HJ, Liu XX, Chu WC, et al. (2014). Brainstem infarcts predict REM sleep behavior disorder in acute ischemic stroke. BMC Neurol, 14:88.

[103] Medeiros CA, de Bruin PF, Paiva TR, Coutinho WM, Ponte RP, de Bruin VM (2011). Clinical outcome after acute ischaemic stroke: the influence of restless legs syndrome. Eur J Neurol, 18:144-149.

[104] Lee SJ, Kim JS, Song IU, An JY, Kim YI, Lee KS (2009). Poststroke restless legs syndrome and lesion location: anatomical considerations. Mov Disord, 24:77-84

[105] Ruppert E, Bataillard M, Namer IJ, Tatu L, Hacquard A, Hugueny L, et al. (2017). Hyperdopaminergism in lenticulostriate stroke-related restless legs syndrome: an imaging study. Sleep Medicine, 30:136-138.

[106] Sechi G, Agnetti V, Galistu P, Murgia B, Marrosu F, Puligheddu M, et al. (2008). Restless legs syndrome and periodic limb movements after ischemic stroke in the right lenticulostriate region. Parkinsonism \& Related Disorders, 14:157-160.

[107] Molnar MZ, Lu JL, Kalantar-Zadeh K, Kovesdy CP (2016). Association of incident restless legs syndrome with outcomes in a large cohort of US veterans. J Sleep Res, 25:47-56.

[108] Szentkiralyi A, Volzke H, Hoffmann W, Happe S, Berger K (2013). A time sequence analysis of the relationship between cardiovascular risk factors, vascular diseases and restless legs syndrome in the general population. J Sleep Res, 22:434-442.

[109] Schlesinger I, Erikh I, Nassar M, Sprecher E (2015). Restless legs syndrome in stroke patients. Sleep Medicine, 16:1006-1010.

[110] Gupta A, Shukla G, Mohammed A, Goyal V, Behari M (2017). Restless legs syndrome, a predictor of 
subcortical stroke: a prospective study in 346 stroke patients. Sleep Medicine, 29:61-67.

[111] Reynolds TQ, Roy A (2011). Isolated cataplexy and REM sleep behavior disorder after pontine stroke. J Clin Sleep Med, 7:211-213.

[112] Woo HG, Lee D, Hwang KJ, Ahn TB (2017). Poststroke restless leg syndrome and periodic limb movements in sleep. Acta Neurol Scand, 135:204-210.

[113] Pasic Z, Smajlovic D, Dostovic Z, Kojic B, Selmanovic $S$ (2011). Incidence and types of sleep disorders in patients with stroke. Med Arh, 65:225-227.

[114] McDermott M, Brown DL, Chervin RD (2018). Sleep disorders and the risk of stroke. Expert Rev Neurother, 18:523-531.

[115] Ramar K, Surani S (2010). The Relationship Between Sleep Disorders and Stroke. Postgraduate Medicine, 122:145-153.

[116] Schuiling WJ, Rinkel GJE, Walchenbach R, de Weerd AW (2005). Disorders of sleep and wake in patients after subarachnoid hemorrhage. Stroke, 36:578-582.

[117] Hepburn M, Bollu PC, French B, Sahota P (2018). Sleep Medicine: Stroke and Sleep. Mo Med, 115:527532.

[118] Nakase T, Tobisawa M, Sasaki M, Suzuki A (2016). Outstanding Symptoms of Poststroke Depression during the Acute Phase of Stroke. PLoS One, 11:e0163038.

[119] Whyte EM, Mulsant BH (2002). Post stroke depression: epidemiology, pathophysiology, and biological treatment. Biol Psychiatry, 52:253-264.

[120] Lee EJ, Kim JS, Chang DI, Park JH, Ahn SH, Cha JK, et al. (2020). Depressive Symptoms in Stroke Patients: Are There Sex Differences? Cerebrovascular Diseases, 49:19-25.

[121] de Man-van Ginkel JM, Hafsteinsdottir TB, Lindeman E, Geerlings MI, Grobbee DE, Schuurmans MJ (2015). Clinical Manifestation of Depression after Stroke: Is It Different from Depression in Other Patient Populations? PLoS One, 10:e0144450.

[122] Robinson RG, Spalletta G (2010). Poststroke depression: a review. Can J Psychiatry, 55:341-349.

[123] Ayerbe L, Ayis S, Wolfe CD, Rudd AG (2013). Natural history, predictors and outcomes of depression after stroke: systematic review and meta-analysis. $\mathrm{Br} \mathrm{J}$ Psychiatry, 202:14-21.

[124] Bartoli F, Lillia N, Lax A, Crocamo C, Mantero V, Carra G, et al. (2013). Depression after stroke and risk of mortality: a systematic review and meta-analysis. Stroke Res Treat, 2013:862978.

[125] Cai W, Mueller C, Li YJ, Shen WD, Stewart R (2019). Post stroke depression and risk of stroke recurrence and mortality: A systematic review and meta-analysis. Ageing Res Rev, 50:102-109.

[126] Davis JC, Falck RS, Best JR, Chan P, Doherty S, LiuAmbrose T (2019). Examining the Inter-relations of Depression, Physical Function, and Cognition with Subjective Sleep Parameters among Stroke Survivors: A Cross-sectional Analysis. J Stroke Cerebrovasc Dis, 28:2115-2123.
[127] Wang L, Tao Y, Chen Y, Wang H, Zhou H, Fu X (2016). Association of post stroke depression with social factors, insomnia, and neurological status in Chinese elderly population. Neurol Sci, 37:1305-1310.

[128] Narushima K, Robinson RG (2003). The effect of early versus late antidepressant treatment on physical impairment associated with poststroke depression: is there a time-related therapeutic window? J Nerv Ment Dis, 191:645-652.

[129] Chen Y, Guo JJ, Zhan S, Patel NC (2006). Treatment effects of antidepressants in patients with post-stroke depression: a meta-analysis. Ann Pharmacother, 40:2115-2122.

[130] Li XY, Zhang CX (2020). Comparative efficacy of nine antidepressants in treating Chinese patients with poststroke depression: A network meta-analysis. Journal of Affective Disorders, 266:540-548.

[131] Eskes GA, Lanctot KL, Herrmann N, Lindsay P, Bayley M, Bouvier L, et al. (2015). Canadian Stroke Best Practice Recommendations: Mood, Cognition and Fatigue Following Stroke practice guidelines, update 2015. Int J Stroke, 10:1130-1140.

[132] Gao B, Cam E, Jaeger H, Zunzunegui C, Sarnthein J, Bassetti CL (2010). Sleep disruption aggravates focal cerebral ischemia in the rat. Sleep, 33:879-887.

[133] Li Pi Shan RS, Ashworth NL (2004). Comparison of lorazepam and zopiclone for insomnia in patients with stroke and brain injury: a randomized, crossover, double-blinded trial. Am J Phys Med Rehabil, 83:421427.

[134] Schwartz DR, Carney CE (2012). Mediators of cognitive-behavioral therapy for insomnia: a review of randomized controlled trials and secondary analysis studies. Clin Psychol Rev, 32:664-675.

[135] Wang SB, Wang YY, Zhang QE, Wu SL, Ng CH, Ungvari GS, et al. (2018). Cognitive behavioral therapy for post-stroke depression: A meta-analysis. J Affect Disord, 235:589-596.

[136] Allio A, Calorio C, Franchino C, Gavello D, Carbone E, Marcantoni A (2015). Bud extracts from Tilia tomentosa Moench inhibit hippocampal neuronal firing through GABAA and benzodiazepine receptors activation. J Ethnopharmacol, 172:288-296.

[137] Boschmans SA, Perkin MF, Terblanche SE (1987). Antidepressant drugs: imipramine, mianserin and trazodone. Comp Biochem Physiol C, 86:225-232.

[138] Serchov T, Schwarz I, Theiss A, Sun L, Holz A, Dobrossy MD, et al. (2020). Enhanced adenosine A(1) receptor and Homer1a expression in hippocampus modulates the resilience to stress-induced depressionlike behavior. Neuropharmacology, 162.

[139] Karasawa Y, Araki H, Otomo S (1992). Effects of ketanserin and mianserin on delayed neuronal death induced by cerebral ischemia in Mongolian gerbils. Psychopharmacology (Berl), 109:264-270.

[140] Iddagoda MT, Inderjeeth CA, Chan K, Raymond WD (2020). Post-stroke sleep disturbances and rehabilitation outcomes: a prospective cohort study. Internal Medicine Journal, 50:208-213. 
[141] Sanna E, Busonero F, Talani G, Carta M, Massa F, Peis M, et al. (2002). Comparison of the effects of zaleplon, zolpidem, and triazolam at various $\mathrm{GABA}(\mathrm{A})$ receptor subtypes. Eur J Pharmacol, 451:103-110.

[142] Furihata R, Kizuki J, Yamano Y, Mizoguchi Y, Nakajima S, Nagai K, et al. (2020). High-dose zolpidem abuse in a patient with insomnia comorbid with major depressive disorder. Sleep and Biological Rhythms, 18:155-157.

[143] Park J, Hopwood V, White AR, Ernst E (2001). Effectiveness of acupuncture for stroke: a systematic review. J Neurol, 248:558-563.

[144] Wang HQ, Hou M, Li H, Bao CL, Min L, Dong GR, et al. (2020). Effects of acupuncture treatment on motor function in patients with subacute hemorrhagic stroke: A randomized controlled study. Complementary Therapies in Medicine, 49.

[145] Gallopin T, Luppi PH, Rambert FA, Frydman A, Fort P (2004). Effect of the wake-promoting agent modafinil on sleep-promoting neurons from the ventrolateral preoptic nucleus: an in vitro pharmacologic study. Sleep, 27:19-25.

[146] Bivard A, Lillicrap T, Krishnamurthy V, Holliday E, Attia J, Pagram H, et al. (2017). MIDAS (Modafinil in Debilitating Fatigue After Stroke): A Randomized, Double-Blind, Placebo-Controlled, Cross-Over Trial. Stroke, 48:1293-1298.

[147] Connell CJW, Thompson B, Turuwhenua J, Srzich A, Gant N (2017). Effects of Dopamine and Norepinephrine on Exercise-induced Oculomotor Fatigue. Med Sci Sports Exerc, 49:1778-1788.

[148] Lokk J, Salman Roghani R, Delbari A (2011). Effect of methylphenidate and/or levodopa coupled with physiotherapy on functional and motor recovery after stroke--a randomized, double-blind, placebo-controlled trial. Acta Neurol Scand, 123:266-273.

[149] Ruscher K, Kuric E, Wieloch T (2012). Levodopa treatment improves functional recovery after experimental stroke. Stroke, 43:507-513.

[150] Martinez-Ceron E, Fernandez-Navarro I, Garcia-Rio F (2016). Effects of continuous positive airway pressure treatment on glucose metabolism in patients with obstructive sleep apnea. Sleep Med Rev, 25:121-130.

[151] Morishita S (2009). Clonazepam as a therapeutic adjunct to improve the management of depression: a brief review. Hum Psychopharmacol, 24:191-198.

[152] Handley A, Medcalf P, Hellier K, Dutta D (2009). Movement disorders after stroke. Age Ageing, 38:260266.
[153] Pei Z, Pang SF, Cheung RT (2003). Administration of melatonin after onset of ischemia reduces the volume of cerebral infarction in a rat middle cerebral artery occlusion stroke model. Stroke, 34:770-775.

[154] Ma Q, Reiter RJ, Chen YD (2020). Role of melatonin in controlling angiogenesis under physiological and pathological conditions. Angiogenesis, 23:91-104.

[155] Oakes KD, Coors A, Escher BI, Fenner K, Garric J, Gust M, et al. (2010). Environmental risk assessment for the serotonin re-uptake inhibitor fluoxetine: Case study using the European risk assessment framework. Integr Environ Assess Manag, 6 Suppl:524-539.

[156] Pariente J, Loubinoux I, Carel C, Albucher JF, Leger A, Manelfe C, et al. (2001). Fluoxetine modulates motor performance and cerebral activation of patients recovering from stroke. Ann Neurol, 50:718-729.

[157] Szelenberger R, Kostka J, Saluk-Bijak J, Miller E (2020). Pharmacological Interventions and Rehabilitation Approach for Enhancing Brain Selfrepair and Stroke Recovery. Current Neuropharmacology, 18:51-64.

[158] Allen RP, Ondo WG, Ball E, Calloway MO, Manjunath R, Higbie RL, et al. (2011). Restless legs syndrome (RLS) augmentation associated with dopamine agonist and levodopa usage in a community sample. Sleep Med, 12:431-439.

[159] Garcia-Borreguero D, Larrosa O, de la Llave Y, Verger K, Masramon X, Hernandez G (2002). Treatment of restless legs syndrome with gabapentin: a double-blind, cross-over study. Neurology, 59:1573-1579.

[160] Murasawa H, Kobayashi H, Yasuda SI, Saeki K, Domon Y, Arakawa N, et al. (2020). Anxiolytic-like effects of mirogabalin, a novel ligand for alpha2delta ligand of voltage-gated calcium channels, in rats repeatedly injected with acidic saline intramuscularly, as an experimental model of fibromyalgia. Pharmacol Rep.

[161] Traa BS, Mulholland JD, Kadam SD, Johnston MV, Comi AM (2008). Gabapentin neuroprotection and seizure suppression in immature mouse brain ischemia. Pediatr Res, 64:81-85.

[162] Hesami O, Gharagozli K, Beladimoghadam N, Assarzadegan F, Mansouri B, Sistanizad M (2015). The Efficacy of Gabapentin in Patients with Central Poststroke Pain. Iran J Pharm Res, 14:95-101. 